\title{
Determinants of Problem Loans: Non-performing Loans vs. Loan Quality Deterioration
}

\author{
Hasna Chaibi \\ Correspondence: Hasna Chaibi, Faculty of Economic Sciences and Management, Tunis El Manar University, B.P \\ 248 2092, Tunisia. E-mail: chaibihasna@gmail.com
}

Received: July 19, 2016

doi:10.5539/ibr.v9n10p86
Accepted: August 11, 2016

Online Published: August 30, 2016

URL: http://dx.doi.org/10.5539/ibr.v9n10p86

\begin{abstract}
The growing literature on credit risk determinants provides results that are based on the set of bad loans present in the bank's assets especially non-performing loans. Besides this classic proxy, the present paper examines the determinants of loan quality deterioration by using a qualitative measure. Actually, we take advantage of a detailed dataset containing information on the quality of loans contracted by banks to different Tunisian firms. The study aims to detect if credit risk determinants are different through quantitative and qualitative proxies. We take into account bank-specific indicators that are likely to affect banking credit risk. Overall, the results show that cost inefficiency and bank profitability are common determinants of the credit risk level and the loan quality deterioration, that are differently influenced by bank size and capitalization.
\end{abstract}

Keywords: loan quality deterioration, non-performing loans, ordered probit model, problem loans

\section{Introduction}

According to statistics from the Central Bank of Tunisia's 2014 report, the banking sector represents the main funding source to the Tunisian economy. Actually, the overall volume of credits amount to 60 million dinars (\$28.91 million), where the total customer deposits have reached 51 million dinars (\$24.57 million). Therefore, examining the factors determining problem loans in Tunisian banking sector is an important question that interest banks and mostly regulatory authorities anxious about financial stability. Actually, once these variables are identified, the credit risk will be manageable using these factors.

Literature on credit risk determinants has distinguished two types of factors responsible for increasing problem loans: microeconomic and macroeconomic. Bank-specific determinants are essentially the management efficiency, loan loss provision, leverage, regulatory capital, funding costs, liquidity, non-interest income, ownership concentration, bank size and profitability. However, country-specific determinants of impaired loans consist on the economic growth, unemployment, inflation, lending rates, sovereign debt, interest rate and exchange rate.

Existing studies examine credit risk determinants through different countries and group of countries. Berger and DeYoung (1997) study a sample of US banks during the period 1985-1994. Focusing on efficiency indicators, they test the links between bank-specific indicators and problem loans. They formulate prospective mechanisms, namely 'bad luck', 'bad management', 'skimping' and 'moral hazard' relating to efficiency and capital adequacy. They find that cost efficiency is likely to be a substantial factor indicating future problem loans. Fofack (2005) showed that GDP growth and the real interest rate are important indicators of impaired loans in the sub-Saharan African countries. He attributes the relationship between macroeconomic factors and non-performing loans (NPLs) to the undiversified environment of some economies in the sample and their high exposure to external shocks. Jimenez and Saurina (2006) use a sample of Spanish banks. The results of this study reveal that impaired loans are explained by economic growth, real interest rates and the credit conditions. However, Khemraj and Pasha (2009) examine the loans problem determinants in the Guyanese banking sector. They present evidence that the NPLs' ratio increase significantly with the real effective exchange rate, whereas the GDP growth is negatively associated with the doubtful accounts. Moreover, they conclude that high interest rates and leverage ratio tend to increase NPLs. Recently, Metin and Ali (2015) investigate the relationship between macroeconomic factors, bank-specific factors and NPLs' ratio in Turkey from 2007 to 2013. They engage linear regression models and cointegration approach. They find that NPLs ratio decreases significantly with industrial production index, Istanbul Stock Exchange 100 Index and inefficiency ratio of banks. Dimitrios, Louri and Tsionas (2016) examine the main determinants of non-performing loans in the euro-area banking system for the period 1990-2015. On the microeconomic and macroeconomic variables proposed by the literature, the 
role of income tax and output gap are for the first time investigated and found to be significant.

Another group of studies on credit risk determinants use the method of dynamic panel data. Louzis, Vouldis and Metaxas (2012) employ this approach to examine the determinants of NPLs for different category of loan for the period 2003 to 2009. They present evidence that impaired loans in the Greek banking sector are mostly explained by systematic indicators that are real GDP, growth rate, unemployment rate, real interest rates, and public debt. Moreover, they are explained by some bank-specific factors, especially performance and efficiency. Castro (2013) analyzes the link between the country-specific factors and the banking credit risk in the GIPSI countries over the period 1997-2011. Also employing dynamic panel data approach, he shows that the banking impaired loans increase when GDP growth and the share and housing price indices decrease and rises when the unemployment rate, interest rate, real exchange rate, and credit growth increase. He also observe an important increase in the impaired loans during the recent financial crisis period.

Credit risk determinants are also investigated in Tunisian banking sector. Actually, Zribi and Boujelbène (2011) provide an analysis for Tunisian banking sector and include ten commercial banks over the period 1995-2008. They conclude that the main microeconomic determinants that affect bank credit risk in Tunisia are the ownership structure, prudential regulation of capital and profitability. However, most significant macroeconomic indicators are the rapid growth of GDP, inflation, exchange rate, and interest rate. More recently, Abid, Ouertani and Zouari (2014) employ the dynamic panel data approach on 16 Tunisian banks over the period 2003-2012. They particularly investigate the determinants of households' non-performing loans. The results of this study indicate that households' NPLs in the Tunisian banking sector tend to be significantly affected by GDP growth, inflation, interest rates and management quality.

Nevertheless, the above studies use the classic non-performing loans as a measure for banking loan problem. Therefore, we aim to check whether the loan quality deterioration is determined by the same indicators that for the level of bad loans that exist in bank's assets. Non-performing loans represent our quantitative proxy assessing the level of firms impaired loans in the assets of banks. However, after exploring the information available on bank balance sheets, the impaired loans, we will try to draw some conclusions on credit risk determinants at quality level, by using micro data. Consequently, our research contributes to the existing literature on credit risk determinants by considering qualitative proxy of problem loans in addition to the classic quantitative measure, NPLs. Actually we use detailed dataset which contains information on the quality of loans given by Tunisian banks to several firms. Given that little attention has been paid to investigate the determinants of problem loans at the bank-level solely, and particularly in Tunisian banking sector, we focus on explaining the microeconomic determinants of credit risk.

Our results show that regardless of the credit risk proxy, the problem loans are significantly affected by cost inefficiency and bank profitability, while they are in no way influenced by banking diversification. Moreover, capitalization is a negative determinant of NPLs, whereas bank size is positively correlated with the quality deterioration of loans.

The paper is divided into five sections. In the next section, we formulate the hypotheses linking the bank-specific variables to the credit risk. Section 3 describes the data and the empirical specification of the study. The findings are reported in section 4 and conclusions are presented in section 5 .

\section{The Determining Factors of Credit Risk}

Several studies in the banking literature examine the relationship between country-specific determinants and the problem loans (Nkusu, 2011; Castro, 2013). Nevertheless, a small number of papers focus solely on bank-specific determinants (Berger \& DeYoung, 1997; Podpiera \& Weill, 2008). Consequently, we choose to identify the bank-specific determinants of credit risk in the Tunisian banking sector.

\subsection{Inefficiency: 'Bad management' and 'Skimping' Hypotheses}

Credit risk can be related to efficiency through different sides that have been superbly examined by Berger and DeYoung (1997). They formulate two hypotheses that differ in the direction of the causality. First, the authors base the negative relationship between cost efficiency and risk in banks with loan problems on the 'Bad management hypothesis' that argue that inefficient banks, assessed by low level of cost efficiency, as well as devoting insufficient resources to assess borrower quality, result in the increasing in future NPLs. ${ }^{1}$ Otherwise,

\footnotetext{
${ }^{1}$ We must also mention an alternative hypothesis which predicts a negative sign between cost efficiency and NPLs. Actually, Berger and DeYoung (1997) develop an exogenous reason of this negative relationship that call 'bad luck hypothesis'. NPLs may take place because of unfavourable economic circumstances beyond the banks' control. Consequently, banks must devote more resources to resolve the problem loans.
} 
Berger and DeYoung (1997) formulate the 'skimping hypothesis' if there could be a positive relationship between cost efficiency and risk in failed banks. They argue that when banks decide not to devote effort to screening borrowers, they would appear to be efficient in the short run but with a high number of NPLs in the long-run. Consequently, we can formulate the following hypotheses:

'Bad management' hypothesis: cost efficiency is negatively associated with increases in future NPLs.

'Skimping' hypothesis: high measured efficiency causes increasing number of NPLs.

We now focus on the findings of the previous studies on this topic. In the seminal paper of Berger and DeYoung (1997), the authors use Granger-causality techniques to test the cost efficiency hypothesis on a large sample of US commercial banks for the period 1985-1994. The authors find that there is a negative relationship between cost efficiency and NPLs ${ }^{2}$, supporting the 'bad management' hypothesis. Podpiera and Weill (2008) extend the Granger causality model developed by Berger and DeYoung (1997) by applying GMM dynamic panel estimators on a panel of Czech banks, and also find strong evidence in favour of the 'bad management' hypothesis. Recently, Louzis et al. (2012) employ dynamic panel data methods to examine the determinants of NPLs in the Greek banking sector and also find support to the 'bad management' hypothesis.

\subsection{Capitalization: 'Moral Hazard' Hypothesis}

The moral hazard hypothesis, also developed by Berger and DeYoung (1997), presumes that thinly capitalized banks respond to moral hazard incentives by increasing the riskiness of their loan portfolio, thereby incurring higher NPLs in the future. Actually, managers in low capitalised banks are more likely to assume larger risk because these banks risk lower potential loss in terms of capital, while these managers take advantage from this greater risk in the loan portfolio if profitability increases. Consequently, moral hazard should be positively related to NPLs. Against this back-drop, we formulate and test the following hypothesis:

'Moral hazard' hypothesis: low-capitalization of banks leads to an increase in NPLs.

In this direction, Berger and DeYoung (1997) find evidence supporting the moral hazard hypothesis. They test the banks' risk attitude only for a subsample of US commercial banks with solvency ratio (equity-to-asset ratios) below the sample median. They argue that banks with significant capital likely face less moral hazard incentives. Salas and Saurina (2002) examine macroeconomic and microeconomic variables as determinants to explain NPLs on Spanish commercial and saving banks for the period 1985-1997. They estimate a statistically significant and negative effect of the lagged solvency ratio on NPLs. They support that that banks with thinner capital tend to operate with higher levels of NPLs, which is in line with the 'moral hazard' hypothesis. Nevertheless, this hypothesis does not find support in the Greek banking system in the study of Louzis et al. (2012). Actually, the solvency ratio does not have explanatory power for all NPL types (mortgages, business and consumers).

\subsection{Non-interest Income: 'Diversification' Hypothesis}

$\mathrm{Hu}$, Yang and Yung-Ho (2004) relate Banks' diversification opportunities with loan quality. They argue that banks that can efficiently develop their sources of incomes from operations not associated to loans should be able to decrease successfully credit risk by dropping inducements to finance speculative projects. Actually, non-diversified banks have to accept some risky loans to generate revenue given that the return on loans presents its main source of income. Some studies use bank size as a proxy for diversification opportunities. They argue that having more resources and sufficient experiences and competencies to successfully assess the quality of potential loans, larger banks are less exposed to the adverse selection problems and then to credit risk. However, as bank size can be used to proxy other determinants, we choose to measure bank's diversification opportunities by the non-interest income as a share of total income. Thus, we expect a negative effect of the proportion of non-interest income as a share of total income on NPLs.

'Diversification' hypothesis: the non-interest income ratio is negatively related to NPLs.

In this line of research, Louzis et al. (2012) reject the diversification hypothesis in the Greek banking sector. Actually, the sign of the noninterest income coefficient is negative for all three types of NPLs (consumer loans, business loans and mortgages), but is not statistically significant. They explain these results by the potential "dark sides" of diversification, as noted by Stiroh (2004). Specially, managers of diversified banks can

${ }^{2}$ Following this seminal research, several studies find that failed banks are usually cost inefficient (Wheelock \& Wilson 1995), or that an increase in bad loans is usually preceded by an a raise in cost inefficiency (De Young \& Whalen, 1994). 
undertake an activity where they are not sufficiently experienced and competitive, and therefore increase their risk taking. Moreover, their results do not change even when diversification is proxied by the noninterest income ratio. They explain that size may not totally capture diversification or that large banks may undertake more risky business compared to the activities of smaller banks. However, Salas and Saurina (2002) find a negative effect of bank size on NPLs and argue that bigger size allows for more diversification opportunities, and consequently to less loan problems. Hu et al. (2004) use a panel data set of Taiwanese commercial banks over the period of 1996-1999 and also found that bank size negatively affects the NPLs. Nonetheless, by using the alternative proxy of diversification (the entropy index), the authors reject the diversification hypothesis. Based on the data set, they argue that Taiwanese commercial's bank revenue mainly comes from loans. Consequently, income source diversification cannot lower successfully the credit risk.

\subsection{Size: 'Too Big to Fail' Hypothesis}

Having more resources to assess loans, large banks are more able to improve the quality of loans and consequently decrease the NPLs (Hu et al., 2004). According to this argument, a bank's size is expected to be related negatively to the rate of NPLs. Nevertheless, the 'Too big to fail' (TBTF) hypothesis has been commonly exploited as one of the argument linking bank size's feature with NPLs (Louzis et al., 2012). Stern and Feldman (2004) argue that large-sized banks are more likely to take risk by granting loans even to lower quality borrowers. Actually, it is known that government protects large financial institutions and their creditors from failure. Consequently, larger banks are likely to increase their leverage, and therefore extend loans to lower quality borrowers. Thus, the following hypothesis may be formulated:

'Too Big To Fail' hypothesis: the banks' size is positively related to problem loans.

$\mathrm{Hu}$ et al. (2004) conclude that bank size is related negatively to the rate of NPLs, which supports their argument that large banks have more resources for assessing the quality of loans. Empirical studies do not provide a clear link for a differential performance and risk attitude of TBTF banks. For instance, Boyd and Gertler (1994) dispute that in the 1980s the tendency of US large banks towards riskier portfolios was supported by the US government's TBTF policy. Empirical results of Louzis et al. (2012) are in favour of the TBTF effect on risk-taking. However, Ennis and Malek (2005) test the US banks' performance across size groups over the period 1983-2003 and do not support the evidence for the TBTF hypothesis.

\subsection{Profitability: 'Bad Management' and 'Procyclical Credit Policy' Hypotheses}

The link between past bank's performance, measured by profitability (ROE), and credit risk can be explained by two opposite directions. First, the negative relation between past earnings and future problem loans is justified by bad management hypothesis given that a poorer performance reflects a signal of poor managerial performance. Thus, we test the following hypothesis:

'Bad management II' hypothesis: past performance is negatively associated with increases in NPLs.

Second, the positive sign of the relation between past earning and future problem loans may also be explained by the justification presented by Rajan (1994). Actually, the reasoning is that bank management is likely to inflate current earnings by undertaking negative NPV, especially by resources of more liberal lending policy, at the expense of future problem loans. Thus, we test the following hypothesis:

'Procyclical credit policy' hypothesis: past performance is positively related with NPLs.

Louzis et al. (2012) test both directions of the influence of past bank's earnings on NPLs in the Greek banking system. Their results confirm the negative relation between performance and NPLs, thus supporting the 'Bad management proposition. This finding is also consistent with the majority of previous studies (Berger \& DeYoung, 1997; Barth, Dopico, Nolle \& Wilcox, 2002) which show, in different contexts, that the low quality of assets is the major source of credit risk problems.

\section{Data and Empirical Specification}

This section presents how this paper is designed in terms of sample, data collection, and analysis. We mainly try to answer to the following questions: What are the factors which influence credit risk in Tunisian banks? To which extent the credit risk determinants are affected by the measures of the problem loans?

The purpose of this paper is to explore the factors determining the credit risk in Tunisian banking sector through two measures of problem loans. The data for bank variables are collected from the Tunis Stock Exchange and the information about companies composing banks' loan portfolios are extracted from the Central Bank of Tunisia. Our sample consists of a panel of 10 commercial banks that are listed on the Stock Exchange of Tunis over the period 2001 to 2010. We stop at 2010 mainly because the Central Bank of Tunisia has changed loans' 
classification methodology in 2011 due to the exceptional measures adopted following the revolution. Indeed, banks are required to reschedule loans of firms whose financial situation has been affected by the revolution of January 2011. After 2012, number of observations is relatively very low.

We explain the modeling of the variables that relates credit risk to a number of assumed bank-specific variables widely used in the empirical literature (Metin \& Ali, 2015 ; Louzis et al., 2012; Ahmad \& Ariff, 2007 ; Berger \& DeYoung, 1997). The model to test is:

$$
C R S K_{i t}=\beta_{0}+\beta_{1} I N E F_{i t}+\beta_{2} C A P_{i t}+\beta_{3} N I I_{i t}+\beta_{4} S I Z E_{i t}+\beta_{5} R O E_{i t}+\varepsilon_{i t}
$$

Where:

1. The subscripts $i$ and $t$ denote the cross sectional and time dimension of the panel sample, respectively.

2. CRSK is the dependent variable in the model, which aims at approximating credit risk.

At a first step, CRSK is represented by a quantitative proxy, Non-Performing Loans (NPLs):

At a second step, CRSK is valued by a qualitative proxy: the classified defaulted loans. The Central Bank of Tunisia requires banks to classify their assets. This classification is based on the risk of loss for banks obviously caused by problem loans. The table below defines each of the six classes established by the Central Bank of Tunisia.

Table 1. Asset classification Tunisian banks

\begin{tabular}{ll}
\hline Class & Description \\
\hline 0 & Firm with risk-free loans. \\
1 & The firm repays its credit in time. Nevertheless, its financial situation seems to become difficult. \\
2 & The firm is facing deteriorating financial situation, and the credit repayment become uncertain \\
& with reimbursement ${ }^{3}$ delay between 90 and 180 days. \\
3 & The financial situation is more hard than for firm in class 2 with a reimbursement delay between \\
4 & $\begin{array}{l}180 \text { and } 360 \text { days. } \\
5\end{array}$ \\
& $\begin{array}{l}\text { Firm with a very difficult financial situation conducting to a reimbursement delay of more than } \\
\text { The firm present a reimbursement delay exceeding } 360 \text { days. Moreover, banks engage a legal }\end{array}$ \\
\hline
\end{tabular}

Therefore, credit risk is caused by defaulted loans, i.e. firms that are classified in classes ranging from 2 to 5 .

INEF: Cost inefficiency = Operating expenses/Operating income

CAP: Ratio of capital $=$ Equity capital/Total assets

NII: Non-interest income $=$ Non-interest income/Total income

SIZE: Bank Size $=$ Natural log of total assets

ROE: Profitability $=$ Net income/Total equity

$\varepsilon$ is the error term.

$\beta_{\mathrm{i}}$ : The coefficient of variable $\mathrm{i}$, respectively.

Our variables are mostly represented by ratios. Nevertheless, estimating financial ratios across firms and years certainly produces extreme values. For example, I use a book measure of firm's capitalization by dividing equity capital to the book value of assets. However, this ratio can be negative, so providing extreme values. In order to avoid the effect of extreme outliers, I winsorize the sample variables and ratios at the top and bottom one percentile of their respective distributions.

In a first stage, we regress our model with a quantitative dependent variable. Consequently, CRSK variable is measured by NPLs. We estimate $\mathrm{T}$ statistics using White standard errors clustered by firm and by year, which account for heteroscedasticity and serial correlation (Petersen, 2009; Thompson, 2011).

In a second stage, we are interested in credit quality through the classification of non-performing loans according to the degree of degradation of repayment by the company. Therefore, we use the ordered probit approach to estimate our regression. Actually, we classify different levels of severity of problem loans by creating bad loan statuses ranging from 1 (bad loan) to 4 (very bad loan). Under the ordered probit model, our dependent variable is taking four values as following:

${ }^{3}$ Principal and/or interest. 
CRSK $=1$, when loan of firm $j$ in year t belong to loan class 2 ;

CRSK $=2$, when loan of firm $j$ in year t belong to loan class 3 ;

CRSK $=3$, when loan of firm $j$ in year t belong to loan class 4 ;

CRSK $=4$, when loan of firm $j$ in year $t$ belong to loan class 5 .

\section{Regression Results}

Table 2 reports regression results for the determinants of credit risk in Tunisian banking sector. We report the estimation results for both measures: the credit risk form bank-level (model 1) and the credit risk for firm-level (model 2).

For both measures of credit risk, the coefficients estimates for LLP variable are not statistically significant, and indicate that the level of loan loss provisions present in assets of Tunisian banks don't predict default risk (proxied by NPLs) neither the deterioration in the quality of the counterparty (proxied by the ordered bad loans).

Regarding the cost inefficiency factor, the coefficient is positive and statistically significant in both models. This finding is consistent with the "bad management" hypothesis, and provides support to the findings of Berger and DeYoung (1997) and Louzis et al. (2012). Nevertheless, the result does not support the "skimping" hypothesis. This implies that increase in bank's management inefficiency (or decrease in bank's management efficiency) leads to higher level of non-performing loans' portfolios (model 1), and that unqualified managers are not able to choose good loans (model 2).

The ratio of banks' capital, CAP, has also an impact on the level of credit risk taken by Tunisian banks. Indeed, the coefficient of CAP, in model 1, is negative and statistically significant with risk at a level of 5\%. This result reports that over-capitalized banks are less risk-taker compared with thinly-capitalized banks, supporting the "moral hazard" hypothesis of Berger and DeYoung (1997), indicating that thinly-capitalized banks deal with riskier loans, so that leads to higher NPLs. However, credit risk, as proxied by loan quality deterioration (model 2 ), is positively related to the ratio of capital. However, the coefficient is not statistically significant. Thus, the "moral hazard" hypothesis does not find support from the qualitative proxy. The bank's capitalization level explain the part of NPLs in Tunisian banks' assets but not the quality of borrowers.

Banks' diversification, measured by non-interest income, is negatively associated with NPLs, but positively related to loan quality. Nevertheless, the related coefficient is not statistically significant. Thus, the "diversification" hypothesis does not find support from the Tunisian banking system. This result is consistent with the finding of Louzis et al. (2012), but does not agree with the empirical evidence of Salas and Saurina (2002), which report a negative relation between diversification and NPLs.

Proxied by the natural logarithm of total assets, size is positively linked to the level of credit risk in Tunisian banking sector, but, the corresponding coefficient is not significant. This finding can be explained by the fact that the institution size is almost the same through Tunisian banks. Nevertheless, the coefficient estimate for SIZE variable is not statistically significant in model 2, and indicates that the bank size affects default risk caused by the deterioration of the loans quality present in Tunisian bank assets. This is consistent with Louzis et al. (2012), suggesting that large banks take excessive risks by increasing their leverage under the "too big to fail" presumption, and therefore have more NPLs.

Performance ratio, ROE, is found to be significant and negatively associated with NPLs and loan quality for Tunisian banks. This is consistent with the empirical results of Podpierra et Weil (2008) and Louzis et al. (2012), confirming the 'bad management II hypothesis' and infirming the 'Procyclical credit policy' hypothesis. This means that bank performance reflects the quality of management.

Table 2. Regression results

\begin{tabular}{|c|c|c|c|c|c|}
\hline \multirow[t]{2}{*}{ Variables } & \multicolumn{2}{|l|}{ Model 1} & \multicolumn{2}{|c|}{$\frac{\text { Model } 2}{\text { Ordered probit }}$} & \multirow[t]{2}{*}{$\begin{array}{l}\text { Expected } \\
\text { sign }\end{array}$} \\
\hline & Coefficient & $t$-statistic & Coefficient & $t$-statistic & \\
\hline INEF & $0.055^{* * *}$ & $(2.41)$ & $0.193^{* * * *}$ & $(5.10)$ & $+1-$ \\
\hline CAP & $-0.151^{* *}$ & $(-2.33)$ & 0.024 & $(0.81)$ & - \\
\hline NII & -0.078 & $(-0.63)$ & -0.003 & $(-0.97)$ & - \\
\hline SIZE & 0.023 & $(0.08)$ & $-0.112^{* * *}$ & $(-9.01)$ & + \\
\hline $\mathrm{ROE}$ & $-0.108^{* *}$ & $(-2.18)$ & $-0.026^{* * *}$ & $(-4.38)$ & $+/-$ \\
\hline Constant & $-0.12^{* * * *}$ & $(-8.27)$ & $-3.68^{* * *}$ & $(-14.22)$ & \\
\hline Number of observations & 291 & & 21448 & & \\
\hline Pseudo- $R^{2}$ & 0.23 & & 0.17 & & \\
\hline
\end{tabular}


The table reports the estimates of alternatives dependant variable measures of the following regression specification:

$$
\mathrm{CRSK}_{\mathrm{it}}=\beta_{0}+\beta_{1} \mathrm{INEF}_{\mathrm{it}}+\beta_{2} \mathrm{CAP}_{\mathrm{it}}+\beta_{3} \mathrm{NII}_{\mathrm{it}}+\beta_{4} \mathrm{SIZE}_{\mathrm{it}}+\beta_{5} \mathrm{ROE}_{\mathrm{it}}+\varepsilon_{\mathrm{it}}
$$

Where CRSK correspond to (1) the level of NPLs present in bank assets (model 1), and (2) the ordered bad loans (model 2), INEF is the cost inefficiency, CAP is the ratio of capital, NII is the non-interest income, SIZE is the bank size, and ROE is the bank profitability.

*** Denotes significance at $1 \%, * *$ Denotes significance at $5 \%$.

\section{Conclusion}

The assessment of overall asset quality in the Tunisian banking industry is an important element of prudential surveillance. Existing literature explores the set of NPLs present in banks' assets. Besides this traditional quantitative factor, this paper tries to investigate credit risk determinants through a qualitative proxy, especially the classification of defaulted loans.

Following our empirical study, cost inefficiency and bank profitability seem to be the significant determinants that affect credit risk measured by both qualitative and quantitative ways. Thereby, inefficiency and profitability factors clearly confirm both hypotheses management: 'Bad management I' hypothesis and 'Bad management II' hypothesis. This accordingly calls Tunisian banks to engage high skilled managers to mitigate risk and improve credit risk management. On the other hand, we find that a greater capitalization only increases the set of NPLs in Tunisian banks without influencing the loan's quality, which is contrariwise affected by banking size. Moreover, no evidence is found for the 'diversification' and 'Procyclical Credit Policy' hypothesis.

Our study encloses numerous policy implications. First, there is an evidence that bank's management quality is the most important indicator for future bad loans as for potential deterioration of loans quality through time. Therefore, Tunisian regulators should require a minimum level of managerial performance so as to minimize potential increases in credit risk. Second, regulatory authorities should focus on thinly-capitalized banks with high level of NPLs to avoid potential financial crises. Third, financial analysts should also consider bank size when evaluating the loan quality of banks.

In conclusion, the factors to consider in analyzing the quality of loans that exist in the assets of Tunisian banks are different than those for assessing the overall level of credit risk. Indeed, apart from inefficiency and bank performance, as common indicators, bank capitalization is an important determinant of non-performing loans and bank size is a factor influencing the quality of bank loans.

\section{References}

Abid, L., Ouertani, M. N., \& Zouari, G. S. (2014). Macroeconomic and Bank Specific Determinants of Household's Non-Performing Loans in Tunisia: A Dynamic Panel Data. Procedia Economics and Finance, 13, 58-68. http://dx.doi.org/10.1016/S2212-5671(14)00430-4

Ahmad, N., \& Ariff, M. (2007). Multi-Country Study of Bank Credit Risk Determinants. International Journal of Banking and Finance, 5(1), 135-152.

Banker, R. D., \& Morey, R. C. (1986). The Use of Categorical Variables in Data Envelopment Analysis. Management Science, 32, 1613-1627. http://dx.doi.org/10.1287/mnsc.32.12.1613

Barth, J. R., Dopico, L. G., Nolle, D. E., \& Wilcox, J. A. (2002). Bank Safety and Soundness and the Structure of Bank Supervision: A Cross-Country Analysis. International Review of Finance, 3(3-4), 163-188. http://dx.doi.org/10.1111/j.1369-412X.2002.00037.x

Berger, A., \& DeYoung, R. (1997). Problem Loans and Cost Efficiency in Commercial Banks. Journal of Banking and Finance, 21, 849-870. http://dx.doi.org/10.1016/S0378-4266(97)00003-4

Boudriga, A., Taktak, N. B., \& Jellouli, S. (2009). Banking Supervision and Non-Performing Loans: A Cross-Country Analysis. Journal of Financial Economic Policy, 1(4), 286-318. http://dx.doi.org/10.1108/17576380911050043

Boyd, J., \& Gertler, M. (1994). The Role of Large Banks in the Recent US Banking Crisis. Federal Reserve Bank of Minneapolis Quarterly Review, 18, 1-21.

Castro, V. (2013). Macroeconomic Determinants of the Credit Risk in the Banking System: The Case of the GIPSI. Economic Modeling, 31, 672-683. http://dx.doi.org/10.1016/j.econmod.2013.01.027

DeYoung, R., \& Whalen, G. (1994). Is a Consolidated Banking Industry a More Efficient Banking Industry? 
Office of the Comptroller of the Currency. Quarterly Journal, 13(3).

Dimitrios, A., Louri, H., \& Tsionas, M. (2016). Determinants of Non-Performing Loans: Evidence From Euro-Area Countries. Finance Research Letters, In Press. http://dx.doi.org/10.1016/j.frl.2016.04.008

Ennis, H., \& Malek, H. (2005). Bank risk of failure and the too-big-to-fail policy. Federal Reserve Bank of Richmond Economic Quarterly, 91(2), 21-44.

Fofack, H. (2005). Non-Performing Loans in Sub-Saharan Africa: Causal Analysis and Macroeconomic Implications. World Bank Policy Research Working Paper, 37-69.

Hu, J., Yang, L., \& Yung, H. C. (2004). Ownership and Non-Performing Loans: Evidence from Taiwan's Banks. Developing Economies, 42, 405-420. http://dx.doi.org/10.1111/j.1746-1049.2004.tb00945.x

Jimenez, G., \& Saurina, J. (2006). Credit Cycles, Credit Risk and Prudential Regulation. International Journal of Central Banking, 65-98.

Khemraj, T., \& Pasha, S. (2009). The Determinants of Non-Performing Loans: An Econometric Case Study of Guyana. The Caribbean Centre for Banking and Finance Bi-annual Conference on Banking and Finance, St. Augustine, Trinidad.

Louzis, D., Vouldis, A., \& Metaxas, V. (2012). Macroeconomic and Bank-Specific Determinants of Non-Performing Loans in Greece: A Comparative Study of Mortgage, Business and Consumer Loan $\begin{array}{lllll}\text { Portfolios. Journal of Banking and } & \text { Finance, 36, }\end{array}$ http://dx.doi.org/10.1016/j.jbankfin.2011.10.012

Metin, V., \& Ali, H. (2015). Determining Impacts on Non-Performing Loan Ratio in Turkey. Journal of Applied Finance and Banking, 5(1), 1-11.

Nkusu, M. (2011). Non-Performing Loans and Macrofinancial Vulnerabilities in Advanced Economies. IMF Working Paper, 11(161).

Petersen, M. A. (2009). Estimating Standard Errors in Finance Panel Data Sets: Comparing Approaches. The Review of Financial Studies, 22, 435-480. http://dx.doi.org/10.1093/rfs/hhn053

Podpiera, J., \& Weill, L. (2008). Bad Luck or Bad Management? Emerging Banking Market Experience. Journal of Financial Stability, 4, 135-148. http://dx.doi.org/10.1016/j.jfs.2008.01.005

Rajan, R. (1994). Why Bank Policies Fluctuate: A Theory and Some Evidence. Quarterly Journal of Economics, 109, 399-441. http://dx.doi.org/10.2307/2118468

Salas, V., \& Saurina, J. (2002). Credit Risk in Two Institutional Regimes: Spanish Commercial and Savings Banks. Journal of Financial Services Research, 22, 203-224. http://dx.doi.org/10.1023/A:1019781109676

Stern, G., \& Feldman, R. (2004). Too Big to Fail: The Hazards of Bank Bailouts. The Brookings Institution, Washington, DC.

Stiroh, K. (2004). Do Community Banks Benefit from Diversification? Journal of Financial Services Research, 25, 135-160. http://dx.doi.org/10.1023/B:FINA.0000020657.59334.76

Thompson, S. B. (2011). Simple Formulas for Standard Errors that Cluster by Both Firm and Time. Journal of Financial Economics, 99, 1-10. http://dx.doi.org/10.1016/j.jfineco.2010.08.016

Wheelock, D. C., \& Wilson, P. W. (1995). Explaining Bank Fail-Ures: Deposit Insurance Regulation and Efficiency. Review of Economic and Statistics, 77.

Zribi, N., \& Boujelbène, Y. (2011). The Factors Influencing Bank Credit Risk: The Case of Tunisia. Journal of Accounting and Taxation, 3(4), 70-78.

\section{Copyrights}

Copyright for this article is retained by the author(s), with first publication rights granted to the journal.

This is an open-access article distributed under the terms and conditions of the Creative Commons Attribution license (http://creativecommons.org/licenses/by/4.0/). 